\title{
Financial Liberalization, Savings and the Bank- ing Sector in Bangladesh
}

\begin{abstract}
This paper explores the consequences of financial liberalization policy on the banking sector in Bangladesh. Following a motivating portfolio selection theoretical model on the impact of liberalization, it applies time series techniques with annual banking sector data for the period, FY1981-2008. The study suggests that the main objective of financial liberalization to promote domestic private savings by raising real interest rates has not worked. No significant positive correlation is observed between domestic private savings and the real deposit interest rate. Furthermore, financial liberalization has not improved the efficiency of the banking institutions since high intermediation costs and interest rate spreads still persist.
\end{abstract}

\section{Keywords}

Financial liberalization, Domestic private savings, Interest rate, Efficiency, Co integration

JEL Classifications: E21, E44, E42, C22

\section{Introduction}

Financial liberalization continues to be an important issue in the literature on economic reform in the context of present global financial crisis, and the nationalization and rescue initiatives by advanced economies with a view to restoring confidence in the banking and financial system. Against this backdrop, question marks are being raised regarding the wisdom of the deregulation of the financial sector. Therefore, it is timely to re-examine the effect of financial liberalization in developing countries, particularly in terms of its stated objectives of promoting domestic private savings and the efficient allocation of financial resources. 
Financial deepening and increased financial intermediation has been identified as one of the crucial factors that could promote growth in developing countries; see Levine (1997) for example. Levine (1997) explains the theoretical interrelations between savings, investment, financial markets and economic growth, where financial institutions mobilize savings, allocate resources leading to capital accumulation and technological innovation, culminating in increased economic growth. Therefore, Levine points to two channels through which financial functions may affect economic growth: capital accumulation and technological innovation. The important point is that well functioning financial institutions can raise the fraction of total savings devoted to investment and avoid premature liquidation of capital. Salient to this process is the efficient allocation of investment through various channels, chief among which is the belief that banking sector intermediation provides a more useful avenue for promoting growth enhancing investment.

The evidence regarding financial liberalization augmenting the level of formal sector private savings in developing countries is mixed; see Fry (1995) for a survey. A study of eight Asian countries, reported in Fry (1995), casts doubts on the interest elasticity of saving being significantly positive. Similarly, Gupta (1987) arrives at a similar conclusion from his analysis of 22 Asian and Latin American countries over the $1967-76$ period. A study by World Bank on the impact of financial reforms in five Asian countries, where reform programmes were initiated in the late 1970s (Malaysia in 1978, Sri Lanka in 1977, Philippines in 1980, Indonesia in 1983 and Korea in 1981-82) and three Latin American countries (Chile in 1974, Argentina in 1976 and Uruguay in 1976) concludes that the relationship between savings and the rising real 
interest rate following financial liberalization is at best ambiguous (Cho and Khatkhate 1989). A more recent estimate for Sri Lanka, India, Bangladesh, Indonesia, Korea, Malaysia, Nepal, Pakistan, Philippines, Taiwan and Thailand found that the national savings ratio increased (on average) in the long run by 0.1 percentage point for each 1 percentage point increase in real deposit interest rate (Fry, 1995), but the magnitude is not large enough to warrant much policy significance. The increased proximity of depository institution branches seems to have exerted a substantial influence on national saving ratios by increasing rural savings, notably in Sri Lanka (Fry, 1995).

The purpose of this paper is to examine the effects of financial sector liberalization in Bangladesh. Our contention is that even if financial liberalization increases the number and branches of private sector banks and induces greater financial deepening (the ratio of broad money over GDP), its ultimate success lies in augmenting formal sector saving, and increases in the quality and volume of banking or financial intermediation. This will depend crucially on portfolio choices of wealth holders, who in an uncertain environment may choose to still stick to real and unofficial assets despite rising bank deposit rates. To that end we employ time series techniques to gauge the effect on savings of financial liberalization, as well as analyze the stylised facts of banking efficiency. The rest of the paper is organized as follows: section 2 contains the theoretical framework for the analysis. Section 3 provides the model specification and estimation of the savings function in Bangladesh. Section 4 explains the consequences of financial liberalization policy for banking efficiency in Bangladesh. Finally, section 5 concludes. 


\section{Theoretical framework}

Until the 1960s, the dominant view in the finance and growth literature was Keynesian, arguing that interest rates ought to be kept low in order to promote capital formation (Sen and Vaidya 1997). During this period, the guiding philosophy of governments in many developing countries was one of economic planning with directed credit programmes and interest rate controls. These became popular as a means of allocating scarce resources to 'preferred sectors' at low cost.

This dominant theoretical position was challenged by Ronald McKinnon (1973) and Edward Shaw (1973). They termed most developing economies as "financially repressed". They described financial repression - indiscriminate "distortions of financial prices including interest rates and foreign-exchange rates" (Fry 1995: 20). In other words, financial repression - a combination of heavy taxation, interest rate controls and government participation in the credit-allocation process - would lead to both a decrease in the depth of the financial system and a loss of efficiency with which savings are intermediated (Sen and Vaidya 1997). The proponents of financial reform argued that financial liberalization tends to raise ratios of domestic private savings to income (Shaw 1973). Therefore, it would lead to significant economic benefits through more effective domestic saving mobilization, financial deepening and efficient resource allocation. The core argument of the McKinnon-Shaw thesis is that savings are assumed to be positively related to the real rate of interest, and that an administratively determined nominal interest rates holds the real interest rate below its market equilibrium level. The theory of financial 
liberalization (McKinnon 1973; Shaw 1973) also contends that savings will be allocated and invested more efficiently in a liberalized environment with financial intermediation, than when savings are invested directly in the sector in which it takes place, without financial intermediation.

There are a number of caveats to the Mckinnon-Shaw hypothesis. First, as pointed out by Thirlwall (2005), the rise in real interest rates after liberalization will make wealth holders richer and they may choose to save a lower proportion of their income. Thus, a rise in interest rates may induce a wealth effect away from savings, even if there is a positive substitution effect towards more bank deposit saving. Secondly, saving may be mainly out of profit income; this Kaldorian view is discussed in Stockhammer (1999). If this is the case, then most productive investment is mainly out of retained profits. Thirdly, and in our view most importantly, are portfolio decisions regarding the composition of savings after liberalization. Most official private savings data is based on investment data, and not other forms of saving which can include unofficial stores of value in informal markets. Financial liberalization may not encourage investors to offload these informal assets in favour of stores of value such as bank deposits which enhance financial intermediation.

We turn to the motivating model for the econometric estimations below. Our framework uses Tobin's (1969) portfolio-balance model to analyse the choices that agents make in holding domestic currency deposits versus alternative stores of value (such as precious metals, foreign currency, and other hedges). While it is not a theory about changes to the supply of savings, it is a theory about its allocation and the extent of formal sector financial intermediation. It is based upon the classic Tobin (1969) multi-asset or 
portfolio-balance model. In this setting, various assets are gross substitutes for each other, provided there are three or more assets. The analysis in this section also draws on Taylor's (1983, chapter 5) extension of the Tobin model for developing countries. In a setting of several assets much hinges on the relative substitutability among different assets that are gross substitutes.

Following Taylor (1983, chapter 5) total wealth $(W)$ is composed of three assets: physical capital $(K)$, domestic money $(H)$ and 'gold' $(Z)$ which is a bybrid asset (consisting of such items as precious metals, foreign currency, other informal sector investments):

$$
W=P K+H+P_{z} Z
$$

$P$ and $P_{z}$ represent the market prices of capital and 'gold' respectively. Equation (1) corresponds to the adding-up condition for total wealth, where the sum of the partial derivatives with respect to wealth must equal unity. The stock of capital $(K)$ is fixed during the period of analysis.

$H$ is high-powered money, equivalent to commercial bank reserves. For the sake of simplicity, commercial banks are assumed to lend only to firms to finance working capital $(Q)$. But the public deposit money with banks $\left(D_{P}\right)$, as do firms $\left(D_{f}\right)$. Thus deposits with banks' are:

$$
H=c\left(D_{p}+D_{f}\right), D_{f}=Q
$$

$Q$ represents financing of working capital, the purchase of intermediate inputs and the payment of wages by firms' in a cash-in-advance situation, and $c$ represents the central bank imposed reserve requirements on bank deposits, $c$ $<$ 1. Bank loans take the form of advances to firms. Firms also borrow from the informal 'gold' market. 
A key feature of the model is that the interest rate $(r)$ that clears the market for bank loans (made only to firms) is endogenous, whereas the interest rate on deposits in banks $\left(r_{d}\right)$ is an exogenous parameter. The important point is that an increase in $r$ is akin to financial deepening as it signifies a greater volume of bank intermediation. On the other hand, raising the deposit rate is equivalent to financial liberalization, and should induce new commercial bank entry. There could, however, be a greater risk associated with a higher deposit rate $(\varrho)$ accompanying financial liberalization due to the lack of appropriate prudential bank regulation and other political uncertainties. The demand function for deposits made by the public may take the form:

$$
D_{p}=h\left(r, r_{d}-\rho, \pi\right) W
$$

The public holds a fraction of total wealth in bank deposits, whose real return is $r_{d}-\pi_{b}$ (monetary inflation). The parameter $\pi$ represents the relative appreciation of the value of 'gold', $\pi_{z}$ relative to monetary inflation $\pi_{b}: \pi=\pi_{z}$ $\pi_{b}$. We postulate that $h_{1}<0$, the partial derivative of the demand for deposits is negatively related to loan market clearing rate, as household wealth holders lend directly to firms. The partial derivative with respect to the deposit rate is normally positive $\left(h_{2}>0\right)$, moderated by a risk factor. The demand for deposits with banks will be declining in the relative rate of 'gold' appreciation, $h_{3}<0$.

Equilibrium in the loan market (zero excess demand) takes the following form:

$$
h\left(r, r_{d}-\rho, \pi\right) W+Q-\frac{H}{C}=0
$$


The first term represents the public's demand for deposits in the commercial banking sector, the second term firms' working capital advances from banks that are re-deposited less supply (the last term). The loan market clears in the loan interest rate $r$, which rises with excess demand and vice-versa.

In the 'gold' market equilibrium (demand minus supply with $P_{z}$ rising in response to excess demand and vice-versa) takes the following form:

$$
g\left(r, r_{d}-\rho, \pi\right) W-P_{z} Z=0
$$

The $g($.$) function represents demand for 'gold'. We would expect the demand$ for 'gold' to fall as the loan rates rises $\left(g_{1}<0\right)$, also for demand to rise as the asset is expected to appreciate in value $\left(g_{3}>0\right)$, but we postulate that $g_{2}$ is ambiguous in sign.

The equilibrium condition for the third asset can be dropped by Walras's law. Totally differentiating (4) and (5) and arranging the results in matrix form we obtain:

$$
\left[\begin{array}{cc}
h_{1} W & 0 \\
g_{1} W & -1
\end{array}\right]\left[\begin{array}{c}
d r \\
d P_{z}
\end{array}\right]=\left[\begin{array}{l}
-h_{2} W \\
-g_{2} W
\end{array}\right] d r_{d}
$$

The trace of the Jacobian is $-1+h_{1} W<0$, and the determinant $(D E T)=-h_{1} W$ $>0$. Therefore, the model is stable.

We are now in a position to carry out some comparative statics exercises around an increase in the deposit rate, which is equivalent to financial liberalization.

$$
\frac{d r}{d r_{d}}=\frac{h_{2} W}{D E T}>0
$$

and 


$$
\begin{aligned}
& \frac{d P_{z}}{d r_{d}}=\frac{\left[h_{2} g_{1}-h_{1} g_{2}\right] W^{2}}{D E T}<0 \text { if } g_{2}<0 \\
& \frac{d P_{z}}{d r_{d}}>0 \text { if } \quad g_{2}<0 \text { and } h_{2}<0
\end{aligned}
$$

An increase in the deposit rate will increase the market clearing loan rate in the new equilibrium; see (7). As far as the equilibrium price of 'gold' is concerned (8) we expect it to fall in the 'normal' case, if $g_{2}<0$. This means that as the deposit rate increases, there is a movement away from both 'gold' and capital towards bank deposits. This represents normality, and is more likely to be the case in more stable societies that are on a sustained high growth path. If, however, $g_{2}>0$, it implies that increases in deposit rates encourage more 'gold' holdings, and if $h_{2}<0$, implying that an increase in the deposit rate is accompanied by a more than proportionate perception in the risk of bank deposits, then the 'price' of 'gold' might rise reflecting excess demand for this asset. In this case the effect of financial sector liberalization upon financial intermediation (more bank deposits) is more muted. Most importantly, the holding of the hybrid informal sector asset, 'gold', may not augment reported savings as it does not always enter official investment data.

\section{Empirical evidence}

Two main issues need to be addressed to examine the impact of financial liberalization hypothesis: first, do real interest rates significantly affect domestic private savings, and second, which form of financial deepening seems to be most relevant: is it the number of financial institutions or the volume of financial assets relative to the size of the economy? We argue that liberalization 
leads to an expansion in both areas. Other studies (Chowdhury, 2001) construct an ordinal index of liberalization policies, but such indices, akin to dummy variables, have their limitations, as well as truncating the data and reducing degrees of freedom.

\section{Model Specification: Savings Function}

To examine the impact of financial liberalization on savings behaviour due to financial deepening measured by broad money as a percentage of GDP (M2/GDP) or the expansion of banking institutions (measured by bank branches), two models are considered:

$S_{P}=\alpha_{0}+\alpha_{1}(r d r)+\alpha_{2}(m 2 / g d p)+\alpha_{3} p c i+v$

$S_{P}=\beta_{0}+\beta_{1}(r d r)+\beta_{2} b a n k b r+\beta_{3} p c i+\varepsilon$

Where, $S_{p}=$ Domestic private savings as a percentage of GDP (defined as private domestic investment plus the trade surplus), $R D R=$ Real deposit interest rate, $m 2 / g d p=$ broad money as a percentage of GDP Bankbr $=$ Bank branch institutions, $p c i=$ percentage change $(\log )$ in per capita income and $v$ and $\varepsilon$ are error terms.

\section{Rationale for the Variables}

The inclusion of real deposit interest rate is standard in the savings literature, particularly when the financial liberalization thesis is tested, which suggests private domestic savings rises in response to increases in the real interest rate. The real deposit interest rate is defined as at least a 12 month time 
deposit rate minus inflation. Another explanatory variable, number of bank branches has been used as a proxy of expansion of financial institutions since the empirical evidence (Fry, 1995:467) suggests that this is an important determinant of estimating institutional access to private saving. Also, broad money as a percentage of GDP (M2/GDP) is an indicator of financial deepening/development, and may augment savings. The inclusion of real per capita income growth is also standard in the savings literature because savings is directly associated with output through investment, although the impact of income on savings has been inconclusive (Chowdhury 2001).

Since the study uses time series data for the period, 1981-2008, the data might be non-stationary in character. If the data generating process of the dependent and the explanatory variables are non-stationary, spurious correlations can occur. This means that the regression equation with nonstationary time series variables may have a higher $\mathrm{R}$ square value combined with a low Durbin-Watson statistic, and also is likely to be statistically significant when they are virtually not (Gujarati 2003:806). In order to avoid such misleading statistical inferences, unit root augmented Dickey-Fuller (ADF) tests need to be done for all the variables under investigation in order to check whether the variables have non-stationary data generating processes.

\section{Estimation : Co integration and Error Correction Model}

To test the presence of non-stationarity in the variables, unit root test (ADF test) has been done for each of the variables under investigation (Annex I). The result suggests that variables are non stationary in levels but stationary at first difference (graphs are in appendix A and B). i.e., variables used in the 
model have the order of integration I (1) which becomes order of I (0) at first difference. Therefore, the Engle and Granger Technique (1987) suggests for co-integration analysis.

If the variables under investigation are found co-integrated, there exists a long run relationship between the variables. Therefore, OLS estimation would not be valid since the residual used in the estimation needs correction. In the presence of co integration, the theorem of Engle Granger (1987) can be used to show an Error Correction Model (ECM). Therefore, models (equation 9 and 10) need to be modified including an error correction term (ec), with variables at first difference, which are noted below:

$d S_{P}=\alpha_{0}+\alpha_{1} d(r d r)+\alpha_{2} d(m 2 / g d p)+\alpha_{3} d(p c i)+\alpha_{4} e c_{t-1}+v$

$d S_{P}=\beta_{0}+\beta_{1} d(r d r)+\beta_{2} d($ bankbr $)+\beta_{3} d(p c i)+\beta_{4} e c_{t-1}+\varepsilon$

Where, $e c_{t-1}$ is the lagged residual from the co integrating regression.

\section{Error Correction Model (Equation-11)}

Applying OLS in estimating equation (9) with the variables in levels, the predicted error term is found stationary (significant at 10 percent, Annex II). As such, the variables under investigation are co-integrated and there exists a long-run relationship between private domestic savings and other explanatory variables. This suggests an Error Correction Model (ECM); regressing private 
domestic savings on explanatory variables (at first difference) and lag (one period) residual (Annex III).

The estimated savings function is noted below:

$S_{P}=0.71+0.12 r d r-0.27 m 2 g d p+0.01 p c i-0.31 e c \quad, R^{2}=0.29$

The estimated equation reveals that is (delete) a positive relationship between real deposit interest rate and domestic private savings, but the magnitude of the coefficient is small $\left(\alpha_{1}=0.12\right)$, and also the coefficient is statistically insignificant ( $\mathrm{p}$ value is 0.15 , Annex-III). The negative relationship between financial deepening $(m 2 / g d p)$ and private domestic savings reveals the fact that private savings might not respond to the financial development in certain developing countries. Indeed, the coefficient is also statistically insignificant ( $\mathrm{p}$-value is 0.25 , Annex-III). The estimated coefficient for per capita income is positive, but the coefficient is also statistically insignificant ( $\mathrm{p}$ value 0.63 , Annex-III). The magnitude of the error correction (ec) coefficient suggests that 31 percent deviation corrects in each turn to reach the long-run equilibrium or stability, and this has been found statistically significant at 5 percent level. (p-value 0.05, Annex-III)

\section{Error Correction Model (Equation-12)}

Applying OLS in estimating equation (10) with the variables in levels, the predicted error term is found stationary (significant at 5 percent, Annex IV). Again, the variables under investigation are co-integrated and a long-run relationship exists between the private domestic savings and other explanatory 
variables. Again, an ECM procedure is called for, regressing private domestic savings on explanatory variables (at first difference) and lag (one period) residual (Annex V).

The estimated savings function is noted below:

$S_{P}=0.73+0.08 r d r-0.003$ bankbr $-0.002 p c i-0.36 e c \quad, R^{2}=0.34$

There is a positive relationship between the real deposit interest rate and domestic private savings, but the magnitude of the coefficient is small $\left(\beta_{1}=0.08\right)$ and insignificant ( $\mathrm{p}$ value is 0.27 , Annex-V). The negative relationship between financial institutions (bankbr) and private domestic savings reveals the fact that private savings might not respond to the expansion in the number of financial institutions. The coefficient is also statistically insignificant ( $\mathrm{p}$-value is 0.29 , Annex-V). The estimated coefficient for percapita income also depicts a negative responsiveness of savings with the income, but the result is statistically insignificant ( $\mathrm{p}$ value 0.94 , Annex-V). The magnitude of the error correction (ec) coefficient suggests that 36 percent deviation corrects in each turn to reach the long-run equilibrium or stability, and this has been found statistically significant at 5 percent level. (p-value 0.02 , Annex-V)

Therefore, no systematic pattern or relationship can be drawn from the regression results. However, due to insufficient observations, and also loss of degrees of freedom with the data at first difference, further econometric analyses, such as VECM (vector error correction models) cannot be explored. 
At least three possible explanations for the negative or insignificant relation between the savings ratio and interest rates may be suggested. First, wealth effects that reduce saving may outweigh substitution effect towards saving following a rise in deposit rates; second, there may be very little substitution between financial and real assets, as highlighted in the theoretical model above; and thirdly if higher real interest rates are associated with a higher ratio of foreign capital flows to GDP, which in accounting terms leads to a lower domestic savings ratio, if part of the capital inflows are consumed. Another empirical study of Bangladesh (Chowdhury 2001) on private savings also found a negative relationship between private savings and real interest rates during the post-reform period.

\section{Financial Liberalization in Bangladesh}

From the mid 1970s onwards many developing countries, most notably in Latin America (e.g., Argentina, Brazil, Columbia, Mexico, Uruguay, and Chile) and Asia (e.g., Malaysia, Indonesia, South Korea, Thailand, India, Sri Lanka, Philippines and Pakistan), implemented various Financial Sector Reform Programmes (FSRPs). In Bangladesh financial reforms started in the 1980s. This process had a number of phases. The measures that have already been taken under the programme include the introduction of a market determined interest rate, privatization of state-owned commercial banks and greater freedom for the operation of private sector commercial banks and other financial institutions. The total number of banks increased from 15 to 48 during the period 1980 to 2005 . Although the financial sector, particularly the banking sector, expanded with the passage of time, the savings rate in 
Bangladesh has not improved compared to other Asian developing countries.

Table 1 presents a cross-country comparison of savings as a percentage of GDP: 
Table 1

Gross Domestic Savings as a percentage of GDP: Selected Asian Countries

\begin{tabular}{lcccccc}
\hline Country & $\mathbf{1 9 8 0}$ & $\mathbf{1 9 8 5}$ & $\mathbf{1 9 9 0}$ & $\mathbf{1 9 9 5}$ & $\mathbf{2 0 0 0}$ & $\mathbf{2 0 0 5}$ \\
\hline Bangladesh & 2.1 & 8.6 & 9.6 & 12.6 & 17.8 & 18.1 \\
China & 35.0 & 34.4 & 39.9 & 44.1 & 37.5 & 49.0 \\
India & 15.5 & 21.2 & 22.6 & 25.3 & 24.0 & 29.7 \\
Indonesia & 38.0 & 29.7 & 32.3 & 30.6 & 32.8 & 26.6 \\
Malaysia & 29.8 & 29.9 & 34.5 & 39.7 & 47.3 & 43.5 \\
Pakistan & 6.9 & 5.9 & 11.1 & 15.8 & 16.1 & 12.2 \\
Sri Lanka & 11.2 & 10.2 & 13.8 & 15.3 & 17.4 & 14.6 \\
Thailand & 22.9 & 25.5 & 33.8 & 35.4 & 31.5 & 30.1 \\
\hline Source: World Development Indicators, 2007 & & & &
\end{tabular}

In Bangladesh, according to its Central bank, total deposits as a percentage of GDP increased from 30 percent in 1990 to 41 percent in 2008. Table 2 shows a comparison with Asian economies of the monetization of the economy, measured by broad money (M2) as a percentage of GDP. Again, Bangladesh lags behind other Asian economies, besides war-torn Sri Lanka.

Table 2

Trends in Financial Development (M2/GDP): Selected Asian Economies

\begin{tabular}{lcccccc}
\hline Country & 1980 & 1985 & 1990 & 1995 & 2000 & 2005 \\
\hline Bangladesh & 13.1 & 19.1 & 22.3 & 27.4 & 31.9 & 41.2 \\
China & 33.2 & 47.3 & 70.3 & 88.5 & 129.5 & 150.6 \\
India & 32.8 & 37.5 & 39.9 & 42.0 & 52.0 & 62.2 \\
Indonesia & 13.3 & 21.4 & 34.2 & 43.3 & 50.0 & 40.9 \\
Malaysia & 71.2 & 108.0 & 89.4 & 106.6 & 121.6 & 124.8 \\
Pakistan & 38.7 & 38.0 & 37.1 & 40.9 & 36.8 & 45.2 \\
Sri Lanka & 28.4 & 29.4 & 25.9 & 33.7 & 36.2 & 39.9 \\
Thailand & 38.2 & 58.9 & 68.4 & 78.6 & 111.9 & 104.7 \\
\hline
\end{tabular}

Source: World Development Indicators, 2007

\section{Operational Efficiency}

The main indicator of operational efficiency is the minimization of intermediation cost, the interest rate spread (IRS) between loan and deposit rates. A low IRS is vital for the efficiency and competitiveness of the financial system (Ahmed and Islam 2006b). Historically, developing countries with 
financial imperfections have been characterised by higher spreads due to factors such as absence of competition, burden of non-performing loans (NPLs), high administrative costs, etc. (Islam and Begum, 2004)

Competition among banks is also seen as a desired outcome of the liberalization process. However, there seems to be limits to the beneficial effects of competition for operational efficiency. This is because of economies of scale and scope in banking (Dijkstra 1996). For small banks it is impossible to have an extensive branch network which is necessary to attract deposits. They also have more problems in spreading lending risks through diversification, and tend to be dependent on a few borrowers. In other cases, it is more profitable to offer a range of banking services instead of just a few products, but this also requires larger banks. In fact, there is a rather complex relationship between competition and operational efficiency. If competition increases, operational efficiency first increases (as costs decrease), but after a certain point, operational efficiency of banks decreases (Dijkstra 1996). Indeed, optimum competition depends on the size of the market. Financial intermediaries can substantially reduce transaction costs, developing expertise and also take advantage of economics of scale (Mishkin 2007). Apart from this, the use of technology in banking services is another element which influences efficiency and optimal scale as well.

In Bangladesh, the IRS has been persistently high over the years, which basically indicates a high cost of financial intermediation. The resulting high cost of borrowing discourages private investment, and also puts strains on the government by increasing the cost of servicing public borrowing (Ahmed and Islam 2006a). Indeed, there has been some improvement in reducing 
intermediation costs in Bangladesh, but still the spread is higher than in neighbouring countries, for example, India (Table 3)

Table 3

Interest Rate Spread of Selected South Asian Countries

\begin{tabular}{ccccc}
\hline Year & India & Bangladesh & Sri Lanka & Pakistan \\
\hline 2003 & 6.09 & 6.11 & 3.68 & 6.63 \\
2004 & 5.17 & 5.27 & 4.86 & 5.46 \\
2005 & 4.50 & 5.38 & 5.93 & 6.83 \\
2006 & 4.75 & 5.61 & 7.14 & 6.43 \\
2007 & 4.25 & 5.98 & $\ldots$ & 5.14 \\
\hline \multicolumn{5}{r}{ Source: Publications of respective Central Banks }
\end{tabular}

Interestingly, the IRS in private sector banking, both foreign (FCBs) and domestic (PCBs) banks, is higher than state-owned development banks (DFIs) in Bangladesh, (Figure 1).

Figure 1

Interest Rate Spread by Types of Banks

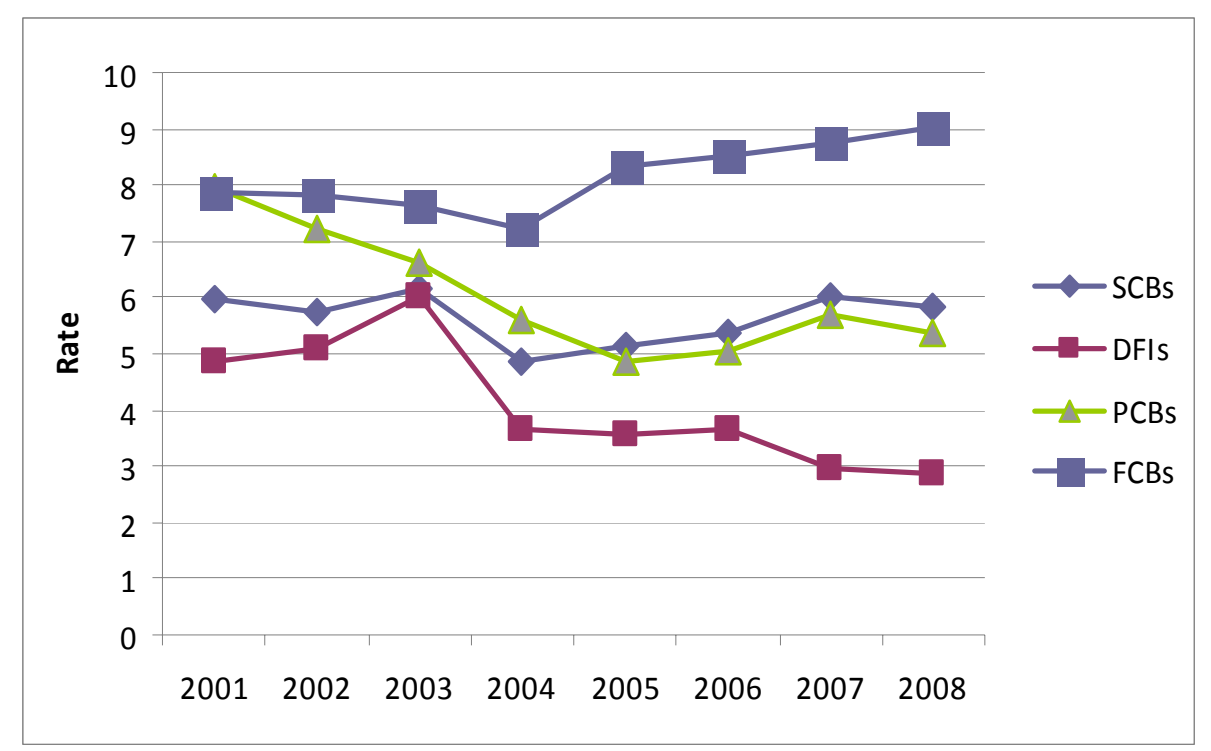

Source: Statistics Department, Bangladesh Bank

Note: $\mathrm{NCBs}=$ Nationalized Commercial Banks, PCBs= Private Commercial Banks, FCBs= Foreign Commercial Banks, DFIs= State-owned Specialized (Development) Banks 


\section{Allocative Efficiency}

The allocation of financial resources is not yet efficient in Bangladesh. Term loans as a percentage of total loan portfolios of the banking sector have been only around 4 to 5 percent until 2007 . However, the proportion increased to 7.86 percent in 2008 (Table 4).

Table 4

Term Loan as a percentage of Total loan portfolio

\begin{tabular}{cc}
\hline FY & Term loan/ Total Loan Portfolio \\
\hline 2003 & 2.81 \\
2004 & 4.35 \\
2005 & 4.97 \\
2006 & 4.29 \\
2007 & 5.43 \\
2008 & 7.86 \\
\hline
\end{tabular}
Source: Statistics Department, Bangladesh Bank

Furthermore, for a proper analysis of allocative efficiency, term loans should be disaggregated in respect of its tenure to observe the availability of loanable funds for long term investment. But due to the lack of adequate data this feature cannot be explained. However, the disaggregated data on term loan disbursements by the types of banks reveals that state owned development banks mainly provide term loans to productive investment compared to private sector commercial banks, especially foreign multinational banks, (Figure 2). 
Figure 2

Term loans by Bank Type

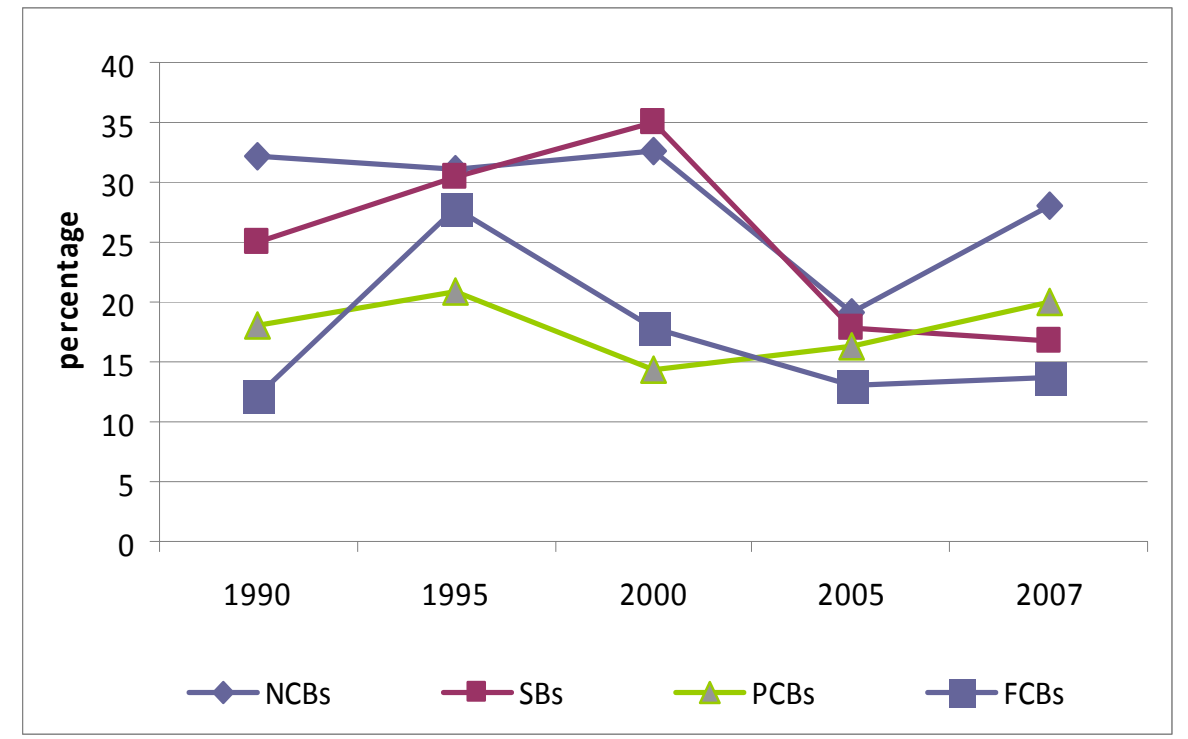

Source: Statistics Department, Bangladesh Bank

Note: NCBs $=$ Nationalized Commercial Banks, $\mathrm{PCBs}=$ Private Commercial Banks, FCBs $=$ Foreign Commercial Banks, SBIs= State-owned Specialized (Development) Banks

\section{Conclusion and Policy Implications}

The study finds that the financial liberalization policies in Bangladesh have not delivered the expected outcome on savings as suggested by the McKinnonShaw hypothesis. It is evident from the econometric analysis that no systematic relationship exists between real deposit interest rate and domestic private savings. One possible explanation, in accounting terms, is that capital inflows, especially the development assistance component, are monetized and consumed thereby depressing aggregate savings. This still leaves us with two other possible channels that may be responsible for financial liberalization not augmenting private savings as a proportion of national income.

First of all the institutional environment may discourage asset swaps away from certain assets, described as the hybrid asset 'gold' in our theoretical portfolio balance model above. The important point being that these assets do 
not enter the official savings data as they are not part of investment. This is more likely in an uncertain institutional environment. Addison, Chowdhury and Murshed (2002) point out that poor general governance and the presence of civil war (political instability) discourage financial deepening. In Bangladesh the regulatory framework is weak. Also, the asset portfolios of banks in Bangladesh are also plagued by toxic loans given out as a result of the process of political patronage, and this is a real problem relative to other developing countries (Chowdhury, 2001). Secondly, the experience of Bangladesh may reflect the fact that liberalization makes savers wealthier, and they consume more, depressing savings. In our view, the first effect, pertaining to institutional factors, may be more relevant in Bangladesh.

Efficiency in the banking sector leaves much to be desired. There are major concerns regarding the prudential regulation of banks, related to capital adequacy and loan loss provision that are highlighted in Chowdhury (2001). Banking institutions are still running inefficiently in terms of operations and allocation of financial resources. Financial intermediation costs are very high, as private sector banks charge excessively to finance investment. Also, only 4 to 5 percent of total bank loan portfolios were disbursed as term loans until 2007, and private sector banks, particularly foreign banks, hardly disburse any term loans. Although financial liberalization calls for privatization and the opening up of the financial market to private sector banking, the Bangladeshi evidence suggests that state owned banks, particularly development banks are still vital in providing investment finance to the productive sector. All in all, financial liberalization in Bangladesh may be yet another case of a bridge too 
far, as highlighted by Caprio, Honohan and Stiglitz (2001) on excessively hasty

banking deregulation and financial liberalization.

\section{References}

Addison, T., A. R. Chowdhury and S. M. Murshed (2002). 'By How Much Does Conflict Reduce Financial Development?' WIDER, Discussion Paper 2002/48.

Ahmed, S. and M.E. Islam (2006a) 'Interest Rate Spread in Bangladesh: An Analytical Review' BB Policy Notes, Series No. 0701, Dhaka: Bangladesh Bank.

Ahmed, S. and M. E. Islam (2006b) 'Interest Rate Responsiveness of Investment Spending in Bangladesh: A VAR Approach', BB Working Paper, Series No.0608, Dhaka: Bangladesh Bank.

Caprio G., P. Honohan, and J.E.Stiglitz (2001) Financial Liberalization: How far, How fast? Cambridge: Cambridge University Press.

Cho, Y. and D. Khatkhate (1989) 'Lessons of Financial Liberalization in Asia: A Comparative Study', World Bank Discussion Papers, Washington, D.C.: World Bank.

Chowdhury, A.R. (2001) 'The Impact of Financial Reform on Private Savings in Bangladesh’ Discussion Paper no. 2001/78, Helsinki: WIDER.

Dijkstra, A.G. (1996) 'Financial Reform and the Efficiency of Intermediation: Banking Performance in Hungary', ISS Working Paper, Series No. 231, The Hague: ISS.

Fry, M.J. (1995) Money, Interest and Banking in Economic Development, London: The Johns Hopkins University Press.

Gujarati, D.N. (2003) Basic Econometrics (4 ${ }^{\text {th }}$ edn), New York: McGraw- Hill.

Gupta, K.L. (1987) 'Aggregate Savings, Financial Intermediation, and Interest Rate', The Review of Economics and Statistics, 69(2):303-311.

Islam, M.E. and N. Begum (2004) 'High Lending Rates in Bangladesh: An Analytical Review', Bank Parikrama, XXVIII \& XXIX: 100-119.

Levine, R. (1997) 'Financial Development and Economic Growth: Views and Agenda', Journal of Economic Literature, 35(2): 688-726.

McKinnon, R. I. (1973) Money and Capital in Economic Development, Washington D.C.: The Brookings Institution.

Mishkin, F.S. (2007) The Economics of Money, Banking, and Financial Markets, New York: Wesley.

Sen, K. and R.R. Vaidya (1997) The Process of Financial Liberalization in India, Delhi: Oxford University Press.

Shaw, E. (1973) Financial Deepening in Economic Development, New York: Oxford University Press. 
Stockhammer, E. (1999) 'Robinsonian and Kaleckian Growth: An Update on Post- Keynesian Growth Theories',Working Paper No.67, pp. 1-20, Vienna: University of Economics.

Taylor, L. (1983) Structuralist Macroeconomics: Applicable Models for the Third World, New York: Basic Books.

Thirlwall, A.P. (2005) 'The determinants of saving in developing countries, and the impact of financial liberalization' in Philip Arestis, Michelle Baddeley, and John McCombie (eds) The New Monetary Policy Implications and Relevance, pp.192-203, Cheltenham and Northampton: Edward Elgar.

Tobin, J. (1969) 'A General Equilibrium Approach to Monetary Theory', Journal of Money, Credit and Banking, 1, 15-29.

\section{Data sources:}

1. Annual Report 2007, Bangladesh Bank

2. Bangladesh Economic Review, 2007-08

3. Bangladesh Bureau of Statistics (BBS) (add), 2008 (delete)

4. Bangladesh Bank Quarterly, various issues.(add)

5. Economic Trends, Bangladesh Bank, various issues.(replace)

6. International Financial Statistics, 2009(March)

7. National Accounts Statistics,BBS, June 2008 (add)

8. Statistics Department, Bangladesh Bank

9. World Development Indicators, 2007 


\section{Appendix - A : Variables in levels}

Domestic private savings

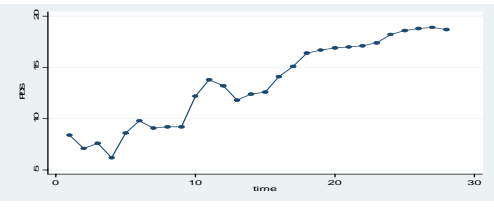

Real deposit interest rate

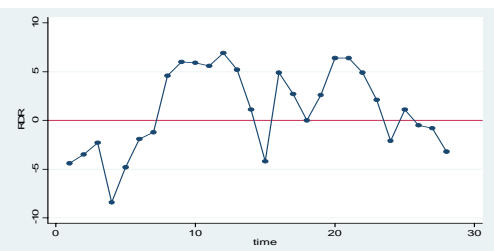

Broad Money as a percentage of GDP

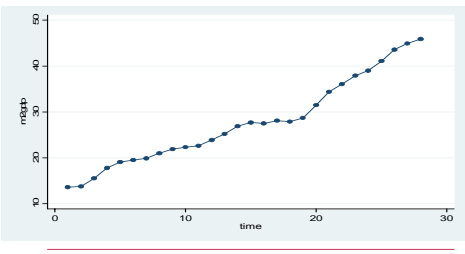

Bank branches

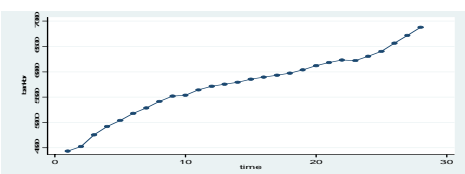

Log per capita income

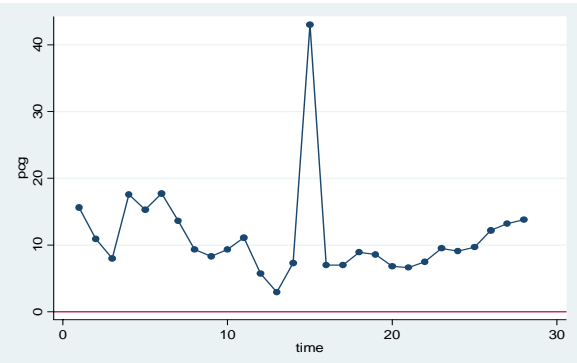


Appendix - B : Variables in First difference Domestic private savings

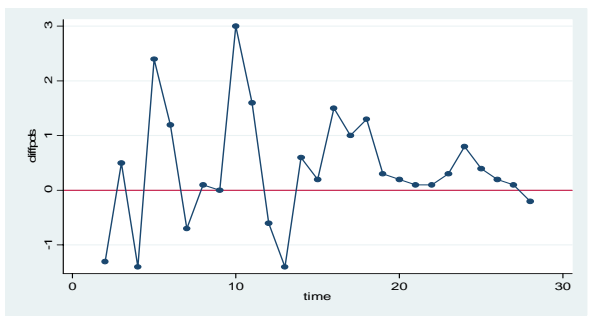

Real Deposit Rate

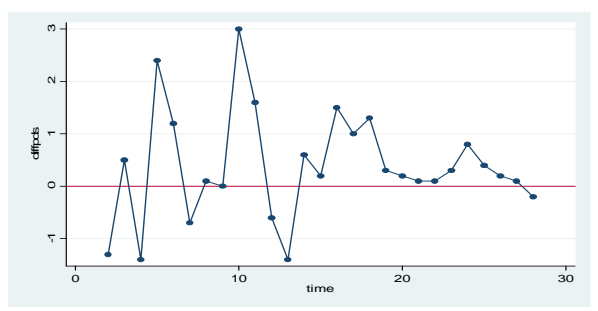

Broad Money as a Percentage of GDP

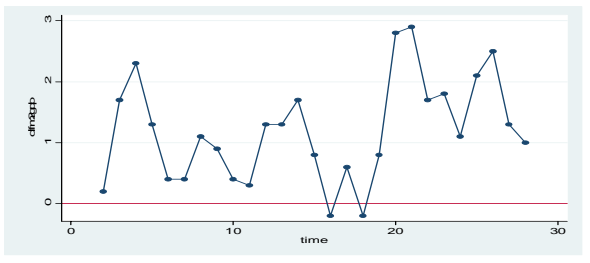

Bank branches

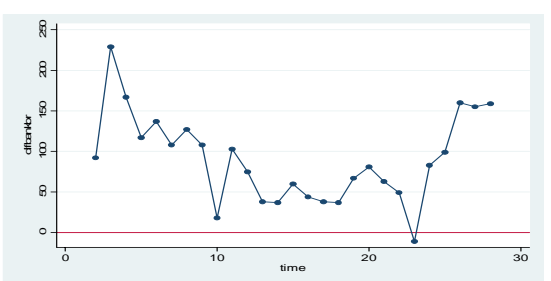

Log per capita income

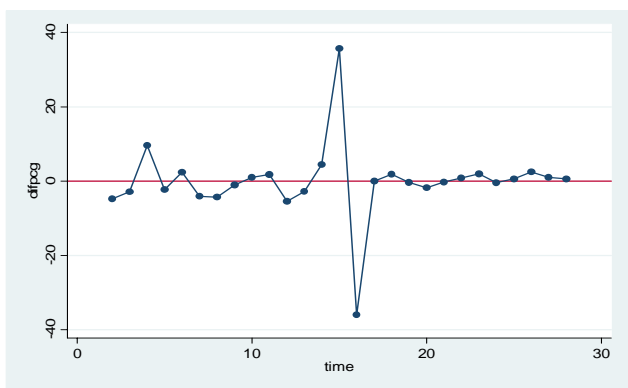

26 


\section{Annex I}

\section{Unit Root Test (ADF Test)}

Before modelling the relationship, the data generating process of the variables (existence of unit roots) is subjected to the Augmented Dicky Fuller (ADF) Test. The null hypothesis $\left(H_{0}\right)$ is that variables under investigation have a unit root; means series is a non stationary process, against the alternative $\left(H_{1}\right)$ is stationary.

Table

Unit root test results (ADF Test)

\begin{tabular}{cccc}
\hline Variables & levels & levels (with trend) & $\begin{array}{c}\text { First Differ- } \\
\text { ence }(\Delta)\end{array}$ \\
\hline $\mathbf{S p}$ & -0.566 & $-3.305^{*}$ & $-5.001^{* * *}$ \\
$\mathrm{rdr}$ & -2.326 & -2.053 & $-5.516^{* * *}$ \\
$\mathrm{bankbr}$ & -1.613 & -2.411 & -2.347 \\
$\mathrm{~m} 2 \mathrm{gdp}$ & 1.514 & -0.555 & $-3.066^{* *}$ \\
$\mathrm{pci}$ & $-5.111^{* * *}$ & $-5.053^{* * *}$ & $-7.615^{* * *}$ \\
\hline
\end{tabular}

Note: (1) Critical values of ADF statistic for levels at $1 \%, 5 \%$ and $10 \%$ level of significance are (-) 3.736, (-) 2.994, and (-) 2.628 (without trend) respectively.

(2) Critical values of ADF statistic for levels at $1 \%, 5 \%$ and $10 \%$ level of significance are (-) $4.362,(-) 3.592$, and (-) 3.235 (with trend) respectively.

(3) Critical values of ADF statistics at first difference at 1\%, 5\% and 10\% level of significance are (-) 3.743, (-) 2.997 and (-) 2.629 respectively.

(4) $* * *$ is $1 \%, * *$ is $5 \%$ and $*$ means $10 \%$ level of significance

The above mentioned table reveals that the hypothesis $\left(H_{0}\right)$ of unit roots in the variables in levels cannot be rejected at $1 \%$ and $5 \%$ level of significance, which proves a non-stationary process of the variables in levels (except per capita income, $p(i)$. On the other hand, ADF tests for unit roots for all the variables in first difference (except bankbr) are integrated of order zero (i.e., stationary process) since they are statistically significant at $1 \%$ and $5 \%$ and $10 \%$ level of significance. If we plot the variables in levels and first difference we get the graphs in appendix A and B. 


\section{Annex II}

Co-integration Analysis: Engle and Granger (1987) Technique

We estimate equation (9) applying OLS method and predict the residual. After doing the unit root test (ADF test) of the predicted residual, we find it stationary at 10 percent level of significance (since p-value is 0.07 )

Table

Unit root test results (ADF Test)

\begin{tabular}{lcc}
\hline & Test Statistic & P-value \\
\hline $\begin{array}{c}\text { Predicted residual } \\
\text { (error term) }\end{array}$ & -2.67 & $0.07^{*}$ \\
\hline Note: (1) Critical values of ADF statistic for levels at $1 \%, 5 \%$ and $10 \%$ significance are $(-)$ \\
$3.736,(-) 2.994$, and $(-) 2.628$ (without trend) respectively. \\
$(2) * * *$ is $1 \%, * *$ is $5 \%$ and $*$ means $10 \%$ level of significance
\end{tabular}

Since the predicted residual for the linear relationship (equation-9) of the variable is stationary at 10 percent level of significance ( $p$-value is 0.07 ), the variables are co-integrated and there exists a long-run relationship between private domestic saving (as a percentage of GDP) and the other explanatory variables. 


\section{Annex III}

\section{Error Correction Model (equation-11)}

Using Error Correction Model (ECM), regressing private domestic savings on explanatory variables (at first difference) and lag (one period) residual:

Table

Dependent Variable: Private Domestic Savings

\begin{tabular}{ccc}
\hline Coefficient & t statistic \\
(Standard Error) & (p value) \\
\hline$\alpha_{0}$ & 0.71 & 2.17 \\
$\alpha_{1}$ & $(0.32)$ & $(0.04)$ \\
$\alpha_{2}$ & 0.12 & 1.51 \\
$\alpha_{3}$ & $(0.08)$ & $(0.15)$ \\
& -0.27 & -1.79 \\
& $(0.23)$ & $(0.25)$ \\
$\alpha_{4}$ & 0.01 & 0.49 \\
& $(0.03)$ & $(0.63)$ \\
R-squared & $\mathbf{- 0 . 3 1}$ & $\mathbf{- 2 . 1 0}$ \\
No. of obs. & $\mathbf{( 0 . 1 5 )}$ & $\mathbf{( 0 . 0 5 )}$ \\
Note: Estimated at 5\% level of significance (95\% confidence interval)
\end{tabular}

The above mentioned table reveals very weak relationship between real deposit rate and domestic private savings (since the magnitude of the coefficient, $\alpha_{1}=0.12$ ) and also corresponding t statistic and $\mathrm{p}$ value suggest that the relationship is statistically insignificant ( $p$ value is 0.15 ). The model however, explains $29 \%$ of the total variation in annual domestic private savings $(\mathrm{R}$-squared $=0.29)$. 


\section{Annex IV}

\section{Co-integration Analysis: Engle and Granger (1987) Technique}

We estimate equation (10) applying OLS method and predict the residual. After doing the unit root test (ADF test) of the predicted residual, we find it stationary at 5 percent level of significance (since p-value is 0.03 )

Table

Unit root test results (ADF Test)

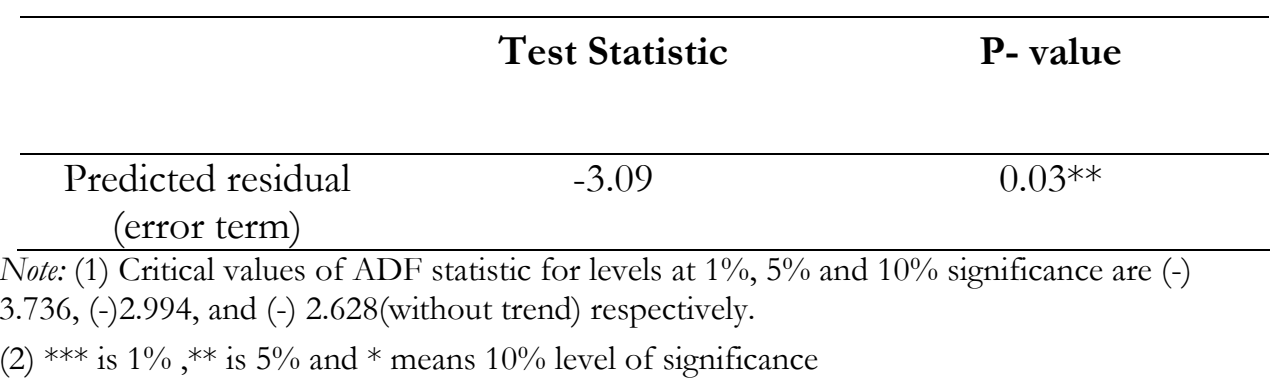

Since the predicted residual for the linear relationship (equation-10) of the variable is stationary at 5 percent level of significance ( $\mathrm{p}$-value is 0.03 ), the variables are co-integrated and a long-run relationship exists between private domestic saving (as a percentage of GDP) and the other explanatory variables. 


\section{Annex V}

\section{Error Correction Model (equation-12)}

Using Error Correction Model (ECM), regressing private domestic savings on explanatory variables (at first difference) and lag (one period) residual:

Table

Dependent Variable: Private Domestic Savings

\begin{tabular}{ccc}
\hline & $\begin{array}{c}\text { Coefficient } \\
\text { (Standard Error) }\end{array}$ & $\begin{array}{c}\text { t statistic } \\
\text { (p value) }\end{array}$ \\
\hline$\beta_{0}$ & 0.73 & 2.08 \\
$\beta_{1}$ & $(0.35)$ & $(0.05)$ \\
$\beta_{2}$ & 0.08 & 1.12 \\
& $(0.07)$ & $(0.27)$ \\
$\beta_{3}$ & -0.003 & -1.08 \\
& $(0.003)$ & $(0.29)$ \\
$\beta_{4}$ & -0.002 & -0.08 \\
& $(.03)$ & $(0.94)$ \\
R-squared & $\mathbf{- 0 . 3 6}$ & $\mathbf{- 2 . 6 4}$ \\
No. of obs. & $\mathbf{( 0 . 1 4 )}$ & $\mathbf{( 0 . 0 2 )}$ \\
\hline Note: Estimated at 5\% level of significance $(95 \%$ confidence interval)
\end{tabular}

Note: Estimated at 5\% level of significance ( $95 \%$ confidence interval)

The above mentioned table reveals a weak relationship between real deposit rate and domestic private savings (since the magnitude of the coefficient, $\beta_{1}=-0.08$ ) and also the corresponding $\mathrm{t}$ statistic and $\mathrm{p}$ values suggest that the relationship is statistically insignificant ( $\mathrm{p}$ value is 0.27 ). The model however, explains $34 \%$ of the total variation in annual domestic private savings $(\mathrm{R}$-squared $=0.34)$. 